also expensive (clomiphene costs $£ 3.50$ - $£ 4.75$ each cycle whereas buserelin and follicle stimulating hormone cost $£ 451$ - $£ 2307$ each cycle), which makes it difficult to recommend this as the primary method of inducing ovulation in women with polycystic ovarian disease. If, however, the value of the ratio of luteinising hormone concentration to follicular diameter in predicting spontaneous abortions is confirmed this could be used to monitor women given clomiphene to induce ovulation. If high ratios were found the women could be advised to use barrier methods of contraception, and if a high ratio occurred in successive cycles pituitary suppression could be started.

Maggregor $\mathrm{AH}$, Johnson JE, Bunde $\mathrm{CA}$. Further clinical experience with clomiphene ciurate Ferul Suril 1968:19:616-20.
2 Yen SSC. The polycystic ovary syndrome. (lin Endocrnol 1980;12:177-208. Homburg R, Armar NA, Eshel A, Adams J, Jacobs HS. Influence of serum luteinising hormone concentrations on ovulation, conception, and early pregnancy loss in polycystic ovary sundrome. Br Med f 1988:297:102t-6.

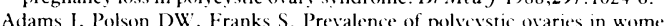

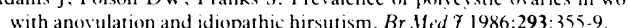
whe

Kerin JF, Lui JH, Phillipou G, Yen SSC. Evidence for a hypothalamic site of action of clomiphene citrate in women. 7 Clin Endocrinol Metah 1985;61:265.

7 Judd SJ, Alderman J, Bowden J, Michailov L. Evidence of involvement of opiate neurons in mediating the effect of clomiphene citrate on gonadotrophin-releasing hormone neurons. Fertil Steril 1987;47:574-8.

8 Mikkelson TJ. Single dose pharmacokinetics of clomiphene citrate in normal volunteers. Fertil Steril 1986:46:392-6

9 Tsafriri A. Pomerantz SH. Ooçte maturation inhibitor. Clm Endocrnol 1986:15:157-70.

10 Stanger JD, Yovitch JL. Reduced in vitro fertilisation of human oocytes from patients with raised hasal luteinising hormone levels during the follicular phase. Br 7 Obstet (junaecol 1985;92:385-90.

Accepted 9 November 1989

\title{
Serological diagnosis of infection with human herpesvirus type 6
}

\author{
William L Irving, Anthony L Cunningham
}

\begin{abstract}
Objective-To identify clinical consequences of acute human herpesvirus type 6 infection by hypothesising that the virus will induce similar clinical syndromes to cytomegalovirus.

Design-Examination of consecutive serum samples from patients with illnesses compatible with acute cytomegalovirus infection or exanthem subitum by indirect immunofluorescence for the presence of antibodies to human herpesvirus type 6. An IgG absorption step was included to avoid false positive and negative results for IgM. The criterion standard for diagnosis of human herpesvirus type 6 infection was the presence of IgM human herpesvirus type 6 antibody (titre $>20$ ) and a rising titre of IgG human herpesvirus type 6 antibody without serological evidence of alternative infection.
\end{abstract}

Setting-Routine viral diagnostic and reference laboratory in the largest teaching hospital in Sydney.

Patients-341 Consecutive serum samples were analysed from patients with hepatitis (147 samples); infectious mononucleosis-like illness (106); screens for toxoplasma, other viruses, rubella, cytomegalovirus, and herpesvirus (38); fever in an immunocompromised patient (eight); unusual neurological (nine) or haematological syndromes (14); splenomegaly (six); and rash in a child (13).

Results - Three cases of acute human herpesvirus type 6 infection were identified: in one patient aged 65 with a previous diagnosis of acute non-A non-B hepatitis, one aged 25 with a glandular fever-like illness, and one aged 6 with a glandular fever-like illness. All three illnesses resolved completely. 15 Further serum samples were positive for human herpesvirus type 6 antibody but were also diagnostic for acute infection with other viruses (cytomegalovirus (nine), Epstein-Barr virus (three), and HIV (one)) or had a titre of IgM human herpesvirus type 6 antibody $<\mathbf{2 0}$ (two).

Conclusions-Acute human herpesvirus type 6 infection in immunocompetent patients may result in a mononucleosis-like illness or an acute but self limiting hepatitis.

\section{Introduction}

Human herpesvirus type 6 is a recently identified human lymphotropic virus which shows tropisms for diverse cells in vitro. ${ }^{1-3}$ Serological surveys suggest that most adults have been infected by the virus. ${ }^{+}$Primary infection with the virus in infancy may result in exanthem subitum (roseola infantum) ; $^{\text {; }}$ possible clinical consequences of primary infection in older children and adults have not been fully defined.

Among the human herpesviruses, the type 6 virus most resembles cytomegalovirus both morphologically and in genomic homology. ${ }^{67}$ By hypothesising that the virus is likely to behave biologically similarly to cytomegalovirus we selected serum samples arriving in this diagnostic laboratory to screen for evidence of acute infection with human herpesvirus type 6 . The initial sceening strategy was designed to identify not only serum samples containing IgM human herpesvirus type 6 antibody but also those with high titre specific IgG antibody, as such samples might give rise to false negative results for IgM antibody. Serum samples positive on screen testing were then retested for the presence of IgM human herpesvirus type 6 antibody after an IgG absorption step. We describe our initial experience with this strategy, which resulted in the identification of three patients whose illness coincided with serological evidence of acute infection with human herpesvirus type 6 .

\section{Samples and methods}

Serum samples from patients with a history compatible with either an acute cytomegalovirus infection or exanthem subitum were screened. The clinical details were categorised as: (a) hepatitis ( 147 samples); (b) infectious mononucleosis-like illness (106); (c) screen for toxoplasma, other viruses, rubella, cytomegalovirus, and herpesvirus ( 25 cord and 13 maternal samples); (d) fever in an immunocompromised patient (eight); (e) unusual neurological syndromes (nine); $(f)$ unusual haematological syndromes $(14)$; $(g)$ splenomegaly (six); and $(h)$ unexplained rash in a child (13). The samples were selected after the requested diagnostic tests had been performed, thus eliminating those in which an alternative virological cause had already been diagnosed.

The samples were screened by indirect immunofluorescence for the presence of IgM human herpesvirus type 6 antibody at a dilution of one in 20 and for high titre IgG human herpesvirus type 6 antibody at one in 100 dilution with acetone fixed J Jhan cells infected with human herpesvirus type 6 as substrate. Fluorescein conjugated sheep antihuman immunoglobulin (Wellcome) was used as the second antibody for IgG and $F\left(a^{\prime}\right)_{2}$ fragment goat antihuman IgM 
(Kallestad, Texas) for IgM. Serum samples positive for IgM were also tested against acetone fixed uninfected J Jhan cells as a negative control. Fluorescence was scored as negative, equivocal, or positive for $\operatorname{IgM}$ or as negative, equivocal, positive, or strongly positive for IgG. Positive samples on screening, defined as being equivocal or positive for IgM or strongly positive for IgG, were then retested for $\operatorname{IgM}$ after diluting one in 10 in Gullsorb (antihuman IgG, Gull Laboratories) to absorb IgG and remove rheumatoid factor. The diluted samples were left for 15 minutes at room temperature before applying them to test slides. This step was necessary to avoid false negative and false positive tests for IgM.

All samples positive for IgM human herpesvirus type 6 antibody after such treatment were tested for evidence of other acute viral infections that might account for the patient's symptomatology. When possible, earlier and convalescent serum samples were obtained from such patients for testing in parallel with the original specimens

$\operatorname{IgG}$ and $\operatorname{IgM}$ antibodies to cytomegalovirus were measured with commercial enzyme immunoassay kits (Pharmacia), IgM antibody to Epstein-Barr virus with an in house enzyme immunoassay, ${ }^{8}$ and rheumatoid factor with a latex agglutination kit (Wellcome), with serum samples diluted in glycine-saline buffer $(\mathrm{pH}$ $8 \cdot 6)$.

\section{Results}

Serum samples from 341 patients were screened, 265 of which were scored as negative. Table I shows the screen test results of the 76 positive samples. After absorption to remove IgG antibody only 11 of these 76 samples were scored as positive for IgM. Further analysis of these 11 samples showed that in three patients there was strong serological evidence of human herpes-virus type 6 infection (table II); the remaining eight patients included six in whom an alternative diagnosis of infection with cytomegalovirus was possible on the basis of IgM cytomegalovirus reactivity (four positive, two equivocal), and one in whom an infection with Epstein-Barr virus was diagnosed (serum positive for IgM Epstein-Barr virus

TABLE I-Serum samples scored as positive on initial screening

\begin{tabular}{|c|c|c|c|c|}
\hline \multirow{2}{*}{$\begin{array}{l}\text { IgM screening } \\
\text { result }\end{array}$} & \multirow{2}{*}{$\frac{\text { IgG screening result }}{\text { Strong positive }}$} & \multicolumn{3}{|c|}{ Final IgM result } \\
\hline & & Negative & Weak & Positive \\
\hline Positive & $\begin{cases}\text { Yes } & 8 \\
\text { No } & 7\end{cases}$ & $\begin{array}{l}3 \\
6\end{array}$ & $\begin{array}{l}3 \\
0\end{array}$ & $\begin{array}{l}2 \\
1\end{array}$ \\
\hline Equivocal & $\left\{\begin{array}{l}\text { Yes } 11 \\
\text { No } 16\end{array}\right.$ & $\begin{array}{r}3 \\
15\end{array}$ & $\begin{array}{l}4 \\
0\end{array}$ & $\begin{array}{l}4 \\
1\end{array}$ \\
\hline Negative & Yes 34 & 31 & 0 & 3 \\
\hline Total & 76 & 58 & 7 & 11 \\
\hline
\end{tabular}

antibody) (table III). The serum from the remaining patient was also positive for HIV antibody. A serum sample from this patient taken six months previously was negative for HIV antibody, suggesting that his mononucleosis-like illness was owing to HIV seroconversion. Seven serum samples had an IgM human herpesvirus type 6 titre of 10 (weak positive); these comprised three with $\operatorname{IgM}$ cytomegalovirus antibody, two with IgM Epstein-Barr virus antibody, and two in whom no other viral diagnosis was possible.

Of the serum samples positive on screening, 58 were negative for IgM human herpesvirus type 6 antibody after absorption of IgG and of these, 31 were classed in the initial screening as strongly positive for IgG, negative for IgM, representing patients with a high titre of antibody to human herpesvirus type 6 for reasons other than the occurrence of a recent infection with the virus; 18 sera were initially classed as equivocal for $\operatorname{Ig} M$, representing samples in which the fluorescence screening for IgM was presumably. overinterpreted; and nine were initially classed as positive for IgM, all of which were positive for rheumatoid factor, indicating that the IgM results for these sera were false positives.

\section{CASE REPORTS}

Table II shows the serological features of the three patients with human herpesvirus type 6 infection.

Case 1 was a 65 year old woman who became unwell on the eighth day of a trip to Asia, with myalgia, fevers, rigors, sore throat, and abdominal pains. She had only taken chloroquine tablets, and there was no history of blood transfusion, general anaesthesia, or excessive alcohol intake. Her symptoms were unsuccessfully treated with antipyretics. She developed a vesicular eruption in both popliteal fossae and legs on days 9 and 10 , which rapidly resolved. On her return to Australia on day 14, examination disclosed $3 \mathrm{~cm}$ tender hepatomegaly and a palpable spleen but otherwise showed no abnormality. Investigations disclosed normal results with a full blood count and differential and platelet count but abnormal liver function test results, which peaked on day 20 (activities of alkaline phosphatase $650 \mathrm{U} / 1$ (normal range 30-115 U/1), alanine aminotransferase $253 \mathrm{U} / \mathrm{l}(10-47 \mathrm{U} / \mathrm{l})$, and $\gamma$-glutamyltransferase $965 \mathrm{U} / \mathrm{l}(8-43 \mathrm{U} / \mathrm{l})$ and concentrations of albumin and bilirubin within normal ranges), and then gradually returned to normal values after eight weeks. She was discharged after seven days and subsequently remained well.

Case 2 was a 25 year old man who presented with a one week history of fever, sweats, headache, and sore throat. On examination he had a maculopapular rash on his trunk (lasting only 24 hours), cervical and axillary lymphadenopathy, and tender hepatosplenomegaly. Abnormal results on investigation included a white cell count of $3.8 \times 10^{4} / 1$ ( $20 \%$ lymphocytes $)$ and a platelet count of $96 \times 10^{9} / 1$ and abnormal activities of

TABLE II - Serological features of infection with human herpesvirus type 6 in three patients ${ }^{\star}$

\begin{tabular}{|c|c|c|c|c|c|c|c|c|c|c|c|}
\hline \multirow{2}{*}{$\begin{array}{l}\text { Case } \\
\text { No }\end{array}$} & \multirow{2}{*}{$\begin{array}{c}\text { Sex } \\
\text { and age }\end{array}$} & \multirow{2}{*}{$\begin{array}{l}\text { Days } \\
\text { after } \\
\text { onset }\end{array}$} & \multicolumn{2}{|c|}{$\begin{array}{l}\text { Human herpesvirus type } 6 \\
\text { screen test result }\end{array}$} & \multicolumn{2}{|c|}{$\begin{array}{c}\text { Human herpesvirus type } 6 \\
\text { titre }\end{array}$} & \multicolumn{2}{|c|}{ Cytomegalovirus } & \multirow{2}{*}{$\begin{array}{l}\text { Epstein-Barr } \\
\text { virus IgM }\end{array}$} & \multirow{2}{*}{$\begin{array}{l}\text { Rheumatoid } \\
\text { factor }\end{array}$} & \multirow[b]{2}{*}{ Clinical details } \\
\hline & & & $\operatorname{Ig} M$ & $\operatorname{IgG}$ & $\operatorname{IgM} \dagger$ & $\operatorname{IgG}$ & $\operatorname{Ig} M$ & $\operatorname{IgG} \ddagger$ & & & \\
\hline 1 & $\mathrm{~F}, 65$ & $\begin{array}{l}18 \\
40 \\
67\end{array}$ & Equivocal & Strongly positive & $\begin{array}{r}<10 \\
80 \\
80\end{array}$ & $\begin{array}{r}8 \\
256 \\
256\end{array}$ & $\begin{array}{l}\text { Negative } \\
\text { Negative } \\
\text { Negative }\end{array}$ & $\begin{array}{l}1.66 \\
1.49 \\
1.32\end{array}$ & $\begin{array}{l}\text { Negative } \\
\text { Negative }\end{array}$ & Negative & Recovery from non-A non-B hepatitis \\
\hline 2 & $M, 25$ & $\begin{array}{r}7 \\
20 \\
74\end{array}$ & Negative & Strongly positive & $\begin{array}{r}<10 \\
40 \\
<10\end{array}$ & $\begin{array}{r}64 \\
256 \\
256\end{array}$ & $\begin{array}{l}\text { Negative } \\
\text { Negative }\end{array}$ & $\begin{array}{l}0 \cdot 03 \\
0 \cdot 07\end{array}$ & Negative & Negative & Recent hepatitis \\
\hline 3 & $\mathrm{~F}, 6$ & $\begin{array}{r}6 \\
65 \\
77\end{array}$ & Equivocal & Strongly positive & $\begin{array}{r}80 \\
<10 \\
<10\end{array}$ & $\begin{array}{r}256 \\
1024 \\
1024\end{array}$ & $\begin{array}{l}\text { Negative } \\
\text { Negative }\end{array}$ & $\begin{array}{l}0.06 \\
0 \cdot 04\end{array}$ & Negative & Negative & Rash, sore throat, cervical lymphadenopathy \\
\hline
\end{tabular}

*All serum samples were negative for IgM hepatitis A virus antibody and hepatitis B surface antigen (radioimmunoassay, Abbott).

†After treatment with Gullsorb.

fOptical density on enzyme immunoassay. Values $<0 \cdot 2$ are negative. 


\begin{tabular}{|c|c|c|c|c|c|c|c|c|}
\hline \multirow{2}{*}{$\begin{array}{l}\text { Case } \\
\text { No }\end{array}$} & \multirow{2}{*}{$\begin{array}{c}\text { Sex } \\
\text { and age }\end{array}$} & \multicolumn{2}{|c|}{$\begin{array}{l}\text { Human herpesvirus type } 6 \\
\text { screen test result }\end{array}$} & \multirow{2}{*}{$\begin{array}{c}\text { Human herpesvirus } \\
\text { type } 6 \\
\operatorname{Ig} M^{\star}\end{array}$} & \multicolumn{2}{|c|}{ Cytomegalovirus } & \multirow{2}{*}{$\begin{array}{c}\text { Epstein-Barr } \\
\text { virus } \\
\text { IgM }\end{array}$} & \multirow[b]{2}{*}{ Clinical details } \\
\hline & & $\operatorname{IgM}$ & IgG & & IgM & IgG† & & \\
\hline 4 & M, 28 & Positive & Strongly positive & 40 & Positive & $>2 \cdot 00$ & & Fever, non-A non-B hepatitis \\
\hline 5 & M, 55 & Positive & Equivocal & 40 & Equivocal & $>2 \cdot 00$ & & Fever of unknown cause after renal transplantation \\
\hline 6 & $\mathrm{~F}, 21$ & Equivocal & Strongly positive & 40 & Positive & 0.06 & & Non-A non-B hepatitis \\
\hline 7 & $\mathrm{~F}, 19$ & Equivocal & Strongly positive & 40 & Positive & $0 \cdot 14$ & & Lymphocvtosis \\
\hline 8 & $\mathrm{M}, 19$ & Equivocal & Equivocal & 20 & Equivocal & $>2 \cdot 00$ & & Febrile, urobilinogen in urine \\
\hline 9 & $\mathrm{~F}, 49$ & Negative & Strongly positive & 20 & Positive & 0.03 & & Fever of unknown cause after transplantation \\
\hline 10 & $\mathrm{~F}, 11$ & Negative & Strongly positive & 40 & & & Positive & Rash \\
\hline 11 & $M, 18 \ddagger$ & Positive & Strongly positive & 40 & Negative & $1 \cdot 70$ & Negative & Glandular fever in male homosexual \\
\hline
\end{tabular}

^After treatment with Gullsorb.

†Optical density on enzyme immunoassay. Values $<0 \cdot 2$ are negative.

†Classified as possible human herpesvirus type 6 infection because of HIV seroconversion.

alkaline phosphatase (149 U/l), alanine aminotransferase $(675 \mathrm{U} / \mathrm{l})$, and $\gamma$-glutamyltransferase $(224 \mathrm{U} / \mathrm{l})$. His symptoms gradually improved; by day 20 of his illness his abnormal physical signs had resolved, and all values had returned to normal eight weeks later.

Case 3 was a 6 year old girl who presented with a morbilliform rash over her trunk and face lasting 48 hours. She developed a fever, sore throat, and cervical lymphadenopathy over the subsequent three days and was then treated with ampicillin. All symptoms and signs resolved completely over the next four days. Investigations on day 6 showed a white cell count of $3.5 \times 10^{\%} / 1$ ( $57 \%$ lymphocytes) with atypical lymphocytes and a platelet count of $115 \times 10^{9} / 1$ (normal range $150-400)$. Liver function tests were not performed. On day 65 , the white cell count and platelet count had returned to normal.

\section{Discussion}

We have identified three cases of illness associated with the presence of IgM human herpesvirus type 6 antibody (titre $>20$ ) without serological evidence of recent infection with other viruses causing similar symptomatology. In all three cases we were able to show a coincident rise in IgG titre. Serological diagnosis of infection with viruses that are capable of latency is problematic, as IgG titre rises and the presence of IgM may indicate an immune response to viral reactivation rather than to primary infection. Nevertheless, we think that our data provide a foundation for identifying clinical syndromes associated with human herpesvirus type 6 infection in immunocompetent patients and suggest that such infection may result in a mononucleosis-like illness or an acute but self limiting hepatitis.

The hepatitis experienced by our two adult patients resulted in only moderate increase in alanine aminotransferase activity and increased alkaline phosphatase activity, being more similar to that due to Epstein-Barr virus and cytomegalovirus than to hepatitis $\mathrm{A}$ or $\mathrm{B}$. During the time of this survey our laboratory received 37 serum samples from patients with mononucleosis that were positive for IgM Epstein-Barr virus antibody (30 patients) or cytomegalovirus (seven) and 14 serum samples from patients with hepatitis that were positive for IgM Epstein-Barr virus antibody (six) or cytomegalovirus antibody (eight), indicating that human herpesvirus type 6 is a much less common cause of these conditions than Epstein-Barr virus or cytomegalovirus.

Moderate enlargement of cervical nodes without fever in three adults with serological markers suggesting acute human herpesvirus type 6 infection has been described, ${ }^{10}$ but in one of the patients no IgM human herpesvirus type 6 antibody was detected and in the other two only low titre (10) IgM. None of the three patients had a rising IgG titre.

In our study $\operatorname{IgM}$ human herpesvirus type 6 anti- body was most commonly associated with an acute cytomegalovirus infection. The coexistence of $\operatorname{IgM}$ cytomegalovirus antibody and $\operatorname{IgM}$ human herpesvirus type 6 antibody and of simultaneous rises in IgG titres to both viruses has been reported ${ }^{11-13}$ as has the finding of $\operatorname{IgM}$ antibodies to human herpesvirus type 6 and to Epstein-Barr virus in the same serum. ${ }^{10}$ The mechanisms underlying these phenomena remain unclear. Such observations emphasise the need for careful evaluation of serological data in diagnosing herpesvirus infections. Infection with viruses other than herpesviruses may also be associated with the appearance of IgM human herpesvirus type 6 antibody, although this has not been reported yet.

One of our serum samples positive for IgM human herpesvirus type 6 antibody came from a male homosexual patient with an HIV seroconversion illness. Examination of earlier stored serum samples from this patient disclosed that he had been positive for $\operatorname{Ig} M$ cytomegalovirus and human herpesvirus type 6 antibodies two years previously, with the human herpesvirus type 6 antibody persisting, in declining titre, since that time, while his IgM cytomegalovirus antibody had disappeared.

The need for an initial screening test to identify high titre IgG human herpesvirus type 6 sera and the need for the IgG absorption step was illustrated by our finding of three serum samples that were positive for IgM only after absorption of high titre IgG. Presumably the IgM screening test was falsely negative because of IgG competition for antigen binding sites. ${ }^{1+}$ These steps also permitted identification of nine serum samples that gave false positive screen test results for IgM owing to the presence of rheumatoid factor.

The cases reported here may be an underestimate of the incidence of acute human herpesvirus type 6 infection. Serum samples with titres of $\operatorname{IgM}$ human herpesvirus type 6 of $<20$ were not considered to be from cases of human herpesvirus type 6 infection, although retrospective or convalescent serum samples may have permitted demonstration of declining or rising IgM titres.

We thank Dr Richard Tedder, University College and Middlesex School of Medicine, London, for donating human herpesvirus type 6 and J Jhan cells; Dr David Cooper, St Vincent's Hospital, Sydney, for providing serum samples from HIV patients who had seroconverted; and Drs Richard Lucas, Jane Forer, and Karen Oswald for permission to report their cases of acute human herpesvirus type 6 infection.

1 Salahuddin SZ, Ablashi DV, Markham PD, et al. Isolation of a new virus, HBLV, in patients with lymphoproliferative disorders. Science 1986;234: 596-600.

2 Downing RG, Sewankambo N, Serwadda D, et al. Isolation of human lymphotropic herpesviruses from Uganda. Lancet 1987;ii:390.

Tedder RS, Briggs M, Cameron CH, Honess R, Robertson D, Whitte $\mathrm{H}$ A novel lymphorropic herpesvirus. Lancet 1987;ii:390-2.

4 Briggs M. Fox J, Tedder RS. Age prevalence of antibody to human herpesvirus 6. Lancet 1988;i:1058-9.

5 Yamanishi $K$, Shiraki $K$, Kondo T, et al. Identification of human herpesvirus6 as a causal agent for exanthem subitum. Lancet 1988;i:1065-7. 
6 Biberfeld P, Kramarsky B, Salahuddin SZ, Gallo RC. Ultrastructura characterisation of a new human B-lymphotropic DNA virus (huma herpesvirus 6 ) isolated from patients with lymphoproliferative disease. gNCI 1987;79:933-41.

7 Efstathiou S, Gompels UA, Craxton MA, Honess RW, Ward K. DNA homology between a novel human herpesvirus (HHV-6) and huma ytomegalovirus. Lancet 1988;i:63-4.

8 Ho DWT, Field PR, Cunningham AL. The rapid diagnosis of acute EpsteinBarr virus infection by the development of an indirect ELISA for specific $\operatorname{lgM}$ antibody without rheumatoid factor and specific IgG interference. fClin Microbiol 1989;27:952-8.

9 Jacobson IM, Gang DL, Schapiro RH. Epstein-Barr viral hepatitis: an unusua case and review of the literature. Am f Gastroenterol 1984;79:628-32.

10 Niederman JC, Liu CR, Kaplan MH, Brown NA. Clinical and serologica
$817-9$

. Eggers HJ. Seroconversion against human herpesvirus- 6 (and other herpesviruses) and clinical illness. Lancet 1988;ii:273-4

12 Irving WL, Cunningham AL, Keogh A, Chapman JR. Antibody to both human herpesvirus-6 and cytomegalovirus. Lancet 1988;ii:630-1.

13 Larcher C, Huemer HP, Margreiter R, Dierich MP. Serological crossreaction of human herpesvirus-6 with cytomegalovirus. Lancet 1988;ii:963-4.

14 Cohen IR, Norins LC, Julian AJ. Competition between, and effectiveness of $\operatorname{IgG}$ and $\operatorname{IgM}$ antibodies in indirect fluorescent antibody and other tests. f Immunol 1967;98:143-9.

(Accepted 27 October 1989$)$

\title{
General practitioner response to elderly patients discharged from hospital
}

\author{
E Idris Williams, Freda Fitton
}

\begin{abstract}
Objective-To determine the effect of discharge information given to general practitioners on their management of newly discharged elderly patients.

Design-A random sample of 133 elderly patients who had unplanned readmission to a district general hospital within 28 days of discharge was compared with a matched control sample of patients who were not readmitted. Information was gathered from the hospital, the patients, the carers, and the general practitioners about the information that the hospital had sent the general practitioner and the general practitioners' response to this information.
\end{abstract}

Setting-All specialties in a district general hospital.

Patients - 266 Patients aged over 65 representative in the main demographic indices of the population of elderly patients admitted to hospital.

Results-Ten weeks after discharge the doctors had received notice of discharge about 169 of the patients, but fewer than half the discharge notices were received within the first week. General practitioners were dissatisfied with the information in $\mathbf{6 0}$ cases. A general practitioner visited 174 of the patients after their discharge from hospital and three quarters of the visits took place within two weeks of the discharge. These visits were more likely to have been initiated by patients or families than by the doctor, and this was not influenced by the doctor receiving notice of the patient's discharge. Older patients and those who had carers were the most likely to be visited. Nearly half of the carers were dissatisfied with some aspect of general practitioner care, problems with home visiting being the commonest source of complaint.

Conclusions-Hospital communications to general practitioners about the discharge of elderly patients still cause concern, particularly in the time they take to arrive. Written instruction to vulnerable elderly patients asking them to inform their general practitioner of the discharge might be helpful. Carers complained of lack of support, and it is clearly important for someone (either the general practitioner or another health worker) to visit elderly people shortly after their discharge.

\section{Introduction}

As part of a study to determine reasons for early unplanned readmission of elderly patients to hospital, general practitioners' responses to patients' discharge were examined. Previous studies have been concerned about the lack of information given to general practitioners by the hospital and the poor management by general practitioners of patients' resettlement in the community. ${ }^{1-4}$ We examined both these aspects, as well as the views of patients and carers.

\section{Subjects and methods}

The total group consisted of 266 patients aged over 65 and was made up of a random sample of 133 patients readmitted within 28 days of their discharge (study group) and a matched sample of 133 patients who were not readmitted (controls). The reasons for the difference in outcome between the study and control groups and a full description of the methods have been given elsewhere. ${ }^{5}$ The group was representative of the population of elderly patients admitted to hospital in the main demographic indices.

A postal questionnaire was sent to the general practitioners of the 266 patients who took part, and we received completed questionnaires about 212 patients. When appropriate, these data were validated by information given by patients and carers. The doctors gave information about the patients' medical conditions and treatment and also about arrangements for discharge and subsequent consultations at home and at their surgeries.

\section{Results}

Problems relating to either general practitioner care or delay in information reaching general practitioners were not considered to be the principal reason for readmission in any of the 133 patients. However, the failure of general practitioners to visit patients was considered to be a contributory factor in readmission in 15 cases and lack of information to the doctor from the hospital was a contributory factor in 49 cases.

Information about notice of hospital discharge was given by general practitioners in relation to 207 patients. Ten weeks after discharge the doctors had received notice about 71 patients who were readmitted and 98 controls. No notice was received about 30 patients who were readmitted and eight controls $\left(\chi^{2}=\right.$ $15 \cdot 5, \mathrm{df}=1, \mathrm{p}=0 \cdot 001$ ). This was in the form of a brief discharge note or summary letter direct from the hospital. The hospital maintained that discharge notes were sent direct to the general practitioner in 199 cases. Only seven patients were given a discharge note to pass on to the general practitioner, and five patients/carers remembered being told by the hospital to contact their general practitioner. General practitioners were dissatisfied with the discharge information given to them by the hospital in 60 cases. They were very dissatisfied about 13 of these. Inadequate information and late notice about discharge were the most common causes of dissatisfaction. 